\title{
The Effect of Guided Writing Strategy in Writing Skill
}

\author{
Ni Made Lisma Martarini, Ni Nyoman Ayu J. Sastaparamitha \\ Program Studi Teknik Informatika, STMIK STIKOM Indonesia \\ Denpasar, Bali, Indonesia, \\ Email: lismamartarini@gmail.com, ajsasta@gmail.com
}

\begin{abstract}
The present study is dealt with the effect of guided writing strategy through first semester students in STMIK STIKOM INDONESIA. The method of analyzing data in this research was conducted by the descriptive analysis. Before that, simple random sampling was used to determine the sample. Two groups were treated differently. One group treated by a guided writing strategy and the other treated by a conventional writing strategy. The data in this study analyzed solely in a descriptive way. The descriptive analysis of the study includes measures of central tendency or averages (mean, median, and mode) and measures of spread or dispersion (standard deviation, variance, and range). The result showed that when the students were treated by guided writing the mean of the result was 80.08 meanwhile when the students were 0 treated by conventional writing skill was 76.77 . Strengthened by the descriptive analysis, it was found that the mean score of writing competency tests for the students who treated by using guided writing strategy was 80.76 and the mean score of writing competency treated by using conventional writing strategy was 76.76. From the mean score finding, it can be concluded that according to learning strategy, the group of students treated by using guided writing strategy was better than the students treated by using conventional writing strategy.
\end{abstract}

Keywords: writing, guided writing, conventional writing

\section{Introduction}

Writing is one of the four language skills which is just as important as the other three skills. These four skills have become the major focus of English as a foreign language teaching and learning (Harmer, 2007).

Teaching writing is more about a process than about a product. It is the process of exploration of what we know and what we feel about what we know to language (Murray,1972).

Writing is not merely putting down some letters to be words, sentences, or joining them into kind of text (Byrne, 1988). It is a complex skill to be acquired. It involves several components, such as vocabulary and grammar, text management, meaning clarity, and coherency of ideas. Those all can create problems if the students failed in developing one of those components.

According to Byrne (1988), there are three problems when the writer writes. First, psychological problems come from the writer itself. It happens when writing as a solitary activity and without the possibility of interaction or the benefit of feedback, it makes the act of writing difficult. Second, the writer has to compensate for the absence of some features, such as keeping the channel of communication open through their own efforts and ensuring, both through their choice of sentence 
structure and their sentences should relate to each other and sequenced. It is determined as the linguistic problems. Third, since writing is learned through a process of instruction, the writer must master the written form of the language and learn certain structures that may be quite different from what used in a speech for effective communication. Furthermore, the writer also has to learn how to organize the ideas in such a way that they can be understood by the reader. It makes writing a complicated process because it involves mastery of the language as well as the cognitive ability to express ideas in written form.

Writing is a productive skill that needs regular intensive practice and rehearsal. It means that to make good writing, the writer should pass a complex process. Producing a wellwriting product, the writer needs at least four steps: prewriting, drafting, revising, and editing. Prewriting is the step of thinking about the topics of writing. Drafting is the next step to input the ideas into a series of sentences to become a paragraph, the next is revision step that the writer has a revision about the craft of writing, and the fourth step that the writer look whole text if there are still several mistakes about the written product. The writing can then be published if there are no other mistakes (Wich et al, 2006).

In a foreign language teaching to make writing easier learners should have a good motivation to learn. According to Brown (2000), motivation is the most important factor when the learner gets failure or success. Furthermore, Donald in Sardirman (2011) defines motivation as a change of energy in every student which is signed by "feeling" and response from a goal. Therefore, motivation also means a series of effort in some conditions so that the people want to do something and if they are not interested or dislike it they will try to ignore that feeling and do it. According to Ormrod (2014) motivation has six effects on students' learning and behavior. They are motivation which directs behavior toward particular goals, leads to increased effort and energy, increases initiation of and persistence in activity, affects cognitive processes, determine which consequences are reinforcing and punishing, and often enhance performance.

The conventional strategy here is used by the lecturer to assist the students in general not step by step as in guided writing strategy.

The students mostly work on their own work and lectures' reasonability was only giving the score. When students do not do well, the score is low. To make it better, the lecturer should choose the right strategy. According to Eggen et al. (2012) guided writing is one of the approaches where the lecturer teaching guiding the students by specific topics and led the students to understand with it and do it in individual or group. In line with Eggen et al., Oczkus (2007) states that guided writing is an individual or group activity where the students or learners organize their own idea and 
write a text. In this technique, the lecturer demonstrates several kinds of types of text to the students by guiding them during the lesson. All the activity of guided writing strategy can be done by a group or personal activity to produce their' own text.

\section{Statement of the Problem}

Based on the background, the researcher formulates the research question of the present study as follows Is there any significant effect of guided writing on first semester students' writing in STMIK STIKOM INDONESIA?

\section{The objective of the Study}

To find out whether or not there is a significant effect of guided writing on first semester students' writing in STMIK STIKOM INDONESIA?

\section{Theoretical Review}

\section{a. Writing Competency}

Writing is one of the four language skills which is just as important as the other three skills. These four skills have become the major focus of English as a foreign language teaching and learning (Harmer, 2007).

Writing is a combination of process and product. The mean of the process is the act of gathering ideas and keep working until the writer presented the paragraph (Nunan,2005).

Competent people are not only able to perform their knowledge or skills, but also the primary knowledge of their' brain. The people or the students who can we call competent if they can produce something or master in something. In writing skills, the example is when the students can make a written product that can develop their' idea and finished it with a good or excellent idea.

Cited from the Wikipedia encyclopedia (2010), competency is a set of defined behaviors that provide a structured guide enabling the identification, evaluation, and development of the behaviors in individuals. This statement is a concern with someone able to explain something with the structure to evaluate someone. For example the teaching-learning process in the classroom, where the lecturer gives the students theme to write something and perform it in front of the class.

Related to that statement, Brown (2003) also stated that, competence refers to one's underlying knowledge of a system, even or fact. It is focusing on someone able to produce an idea or to perform something. In the classroom, someone or the students' competence can be assessed by tests or examinations. Writing competency is the ability to perform writing task in which the focus in the accuracy, development, and reflective expression of the students; own idea (Schlig, 2008)

Based on the theory above, it can be concluded that competency in writing is the ability of students to produce and manage the idea in the writing form. In this case, the competency writing involves linguistic and cognitive aspects. The linguistics component such as the 
person applies the vocabulary, grammatical structure, meanwhile the cognitive aspect is how the person understands the language, ménage the sentences, and uses the correct utterance in a certain situation. So writing competency is the ability of someone to conduct organizes themselves to make the written product in the correct way and with certain criteria such as the language used, grammatical, vocabulary, and also the organization of a certain paragraph.

\section{b. Process of Writing}

There are several experts who provide different opinions on the writing process. Folse et $\mathrm{Al}$ (2010) state that there are seven steps of the writing process (1) choosing a topic (2) brainstorming (3) outlining (4)writing the first draft (5) getting feedback from a peer, (6) revising the draft (7) proofreading the final draft. There are some different opinions from the experts. Harmer (2004) stated that there are four main elements in the writing process: (1) planning, (2) drafting, (3) editing ( reflecting and revising), and (4) final revision. Oshima and Hogue(2007) also stated in line with Harmer, that there are 4 processes of writing (1) prewriting, (2) organizing, (3)writing, (4) polishing (refusing and editing).

First, pre-writing is always to get ideas, Oshima and Hogue (2007) stated that prewriting is the first step to write something. In these steps, the writer should choose a topic, besides that the writer should collect ideas to compose some supporting sentences to explain the topic. Zemach et $\mathrm{Al}$ (2003) also argue that freewriting is a step to choose a topic before writing something. One of them is collecting some ideas, the writer can get from several techniques. Listing is a prewriting technique in which writers write the topic at the top of a piece of paper and then quickly make a list of the words or phrases that come into the writer's mind. (Oshima and Hogue;2007)

The next step is to organize the idea into a simple outline (Oshima and Hogue;2007). The writer should arrange their idea in a simple outline. After making the outline, the writer continues with a rough draft. Writing a rough draft is using the outline which has done as a guide, (Oshima and Hogue;2007) in writing a guide, the writer does it quickly and without thinking about grammar or pronunciation. they write all the ides with the draft as a guide.

The last step is publishing. This step is done by revising and editing (Oshima and Hogue;2007). In this case, the writer checked what they have written (Zemach et al;2003). They reviewed the structure and content. They can check it by reading the written product silently or loudly, even though crosscheck with friends.

According to Seow (2002), the last steps called a post. Writing the steps includes publishing, sharing, reading aloud, transforming text for the performances in front of the class. Based on the explanation above, the researcher can conclude that the steps of writing are starting by pre-writing 
until post-writing which completed by publishing.

\section{c. Paragraph Structure}

According to Oshima and Hogue(2009), A paragraph is a group of related sentences that discuss one (and usually only one) main idea. A paragraph can be as short as one sentence or as long as ten sentences. The number of sentences is unimportant; however, the paragraph should be long enough to develop the main idea clearly.

Smalley (in Suariningsih,2011) states that a paragraph is a group of sentences that develop one main idea which develops a topic. It means that a paragraph has its own organization. So, the paragraph from both statement said that a paragraph is a group of sentences that contain one core idea.

Winter (1999) states that a paragraph is a form of written communication that contains a minimum of five sentences. Each sentence in a paragraph "talks about" or develops one single main idea. Here if want to make a good paragraph so the writer should construct it by have one main idea and supporting sentences. One paragraph at least has 5 sentences more. The main topic is the main idea of a paragraph. This sentence is the key to the paragraph that will be written (Winter, 1999). Winter (1999) also argue that the topic sentence can be put in the front of the paragraph or the middle or the end of that paragraph, after the writer has the main sentences, then the writer should construct the supporting sentences. Supporting sentences is a helper. By supporting sentences the writers are able to make a beautiful paragraph.

The structure of paragraphs according to Oshima and Hogue (2007) is the topic sentence, supporting sentences, and concluding sentences. In line with Oshima and Hogue (2007), Zemach and Rumisek (2003) also stated that paragraph has three basic parts, they are the topic sentence, supporting sentences, and concluding sentences. (1) The topic sentence is the main idea of the paragraph. It is usually the first sentence of the paragraph and it is mostly the general sentence of the paragraph, Zemach et al. (2003) argue. (2) According to Zemach et al supporting, sentences are sentences that talk about or explain the topic sentence, and it is more detailed ideas that follow the topic sentences. Oshima and Hogue (2007) supporting sentences explain the topic by giving some information in supporting point sentences. So, supporting sentences are sentences that explain some information related to the topic that will be written. (3) Concluding sentences according to Oshima and Hogue (2007) are the signals of the end of the paragraph. It is reminded the reader of the main idea. It is usually located at the end of the paragraph and sometimes just repeat the main topic or just giving the final comment.

Based on the explanation above the researcher can conclude that a paragraph is a group of sentences that explain one main topic. The structure of the paragraph is the main sentences which are usually in the front of a 
paragraph, supporting sentences that are explaining to the related topic, and the last is concluding sentences which is at the end of the paragraph which repeats the main sentence or just giving the final comment.

\section{d. Guided Writing}

Eggan et al. (2012) guided writing is one of the approaches where the lecturer teaching by giving the students examples of the specific topic and lead the students to understand with it. Guided writing can be held in a group of individually. This strategy is really useful in teaching English. The lecturers give the students a problem and they tried to find the solution. Trial and error are recommended and the lecturer as the guide.

The students will open their minds and try to express their own ideas about that topic.

However, writing is really important is the writing curriculum as the primary national strategy states (2007)

Primary National strategies (2007) States that Guided writing is an essential component of a balanced writing curriculum, providing an additional supported step towards independent writing. It contributes to the teaching sequence as exemplified in the Primary Framework.

A product is an important thing in the writing curriculum, by guided writing, the students expected to able has own written. Independent writing is the learning objective here.

In guided writing, students have a big role because in this case, the teaching-learning process is the students centered not the lecturer centered. The lecturer started the teaching-learning process by explaining the students' activities and organizes the students for solving the problem, investigation, and other activities. Solving the problem is the important thing.

Oczkus (2007) states that guided writing is an individual or group activity where the students or learners used word maps to organize that own idea and write a text. Here the expert means that all the activity of guided writing strategy can be a group or person to produce their' own text. In this technique, the lecturer demonstrated several kinds of types of text to the students by guiding them with the picture during the lesson.

In summary, guided writing is a strategy to give the students chance to develop their own idea in the class activity. The activity can be done by the students' group or personal to construct a good text in their own way or independently. Some experts said that there are some reasons why the lecturers should use guided writing in the teaching-learning process. Carin and Sund in Suprihaningrum (2013) states that there are 3 reasons why the lecturer should use this method. The first one is almost all lecturers more comfortable using the expository approach; it is because the strategy is already famous in the world for the year by years. The second is if the lecturers want the scientist students, the students should be active in the class. The third, by guided writing the lecturer will develop the students 
writing competency because as the lecturer finds the different level understanding of the students.

\section{e. Syntax of Guided writing}

Because of guided writing is the part of the discovery study, so the step is adopted based on the problem. The writing process in guided writing strategy according to Whitaker (2009) the steps are to choose a topic, think (brainstorm), research, plan (outline), write, revise, edit, proofread. Closed with the steps of the guided writing, according to the Suprihatiningrum (2012) the steps of the guided writing are explaining the purpose of the study, orientation the students to the problem, formulating the hypothesis, conducting discovery activity, presenting the discovery, evaluating the discovery activities. The steps are:

1. Explaining the purpose of the study

Explaining to the students the purpose of the study and encourage the students to participate in teaching learning process

2. Orientation the students to the problem

Explaining in the simple way what the material

3. Formulating the hypothesis Guiding students formulate appropriate hypothesis issues raised

4. Conducting discovery activity Guiding the students to do the discovery activity to find the information needed.

5. Presenting the discovery
Guiding the students in present the result of the activities and conducing the conclusion.

6. Evaluating the discovery activities

Evaluating all the activities what have been done.

\section{f. Conventional Writing Strategy}

Convention refers to the way in which something is done by most people in general. A person who follows the conventional strategy; what is the traditional and or the way something has been done for a long time is the point of this strategy. According to Hornby (2006) convention means the way in which something is done by most people in general. The conventional writing strategy is a teaching method which usually used by the lecturer in the teaching-learning process in the classroom. It means that this is a conventional strategy that is generally, perform and acceptable by the lecturer in conducting instruction. The conventional writing strategy activity in the class such as (1) the starting point with the short explanation of the theory, definition which the student should remember about it. It is a presentation related to the topic given. (2) the lecturers give the students examples, (3) finally the lecturer gives the students exercises.

From that teaching method, the students become always receive what the lecturer gives. 
Method of Data Collection and Research Instruments

After that simple random sampling was used to determined the sample. Two groups were treated differently. One group treated by guided writing strategy and the other treated by conventional writing strategy. Analyzing data was conducted by the descriptive analysis.

\section{Descriptive Analysis}

Best and Kahn (2001) stated that descriptive statistical analysis limits generalization to the particular group of individuals observed. It means the data in this study will be analyzed solely in descriptive way. The descriptive analysis of the study includes measures of central tendency or averages (mean, median, and mode) and measures of spread or dispersion (standard deviation, variance, and range).

1. Mean

Mean is the most widely used measure of central tendency, or arithmetic average. It is the sum of all the scores in a distribution divided by the number of cases. (Ary, 2010:108)

2. Median

The median is defined as that point in a distribution of measures below which 50 percent of the cases lie.

(Ary, 2010:110)

3. Mode

The mode is the value in a distribution that occurs most frequently. It is the simplest to find of the three measures of central tendency because it is determined by inspection rather than by computation. (Ary, 2010:111)

4. Standard Deviation

Standard deviation is the square root of the variance and a measure of spread or dispersion of scores in distribution. (Best and Kahn, 2003)

5. Variance

Variance is the sum of the squared deviation from the mean, devided by the total numbers of the students in a group. (Best and Kahn, 2003)

6. Range

Range is the simplest measure of dispersion. It can be measured by computing the difference between the highest score and the lowest score. (Best and Kahn, 2003)

\section{Data Description}

Descriptive statistic analysis covers the measures of the central tendency or averages (mean, Median, mode) and measure of spread or dispersion (standard deviation, variance, and range). The presentation of all data of those measurements consists of data obtained from posttest of experimental group and control group. 


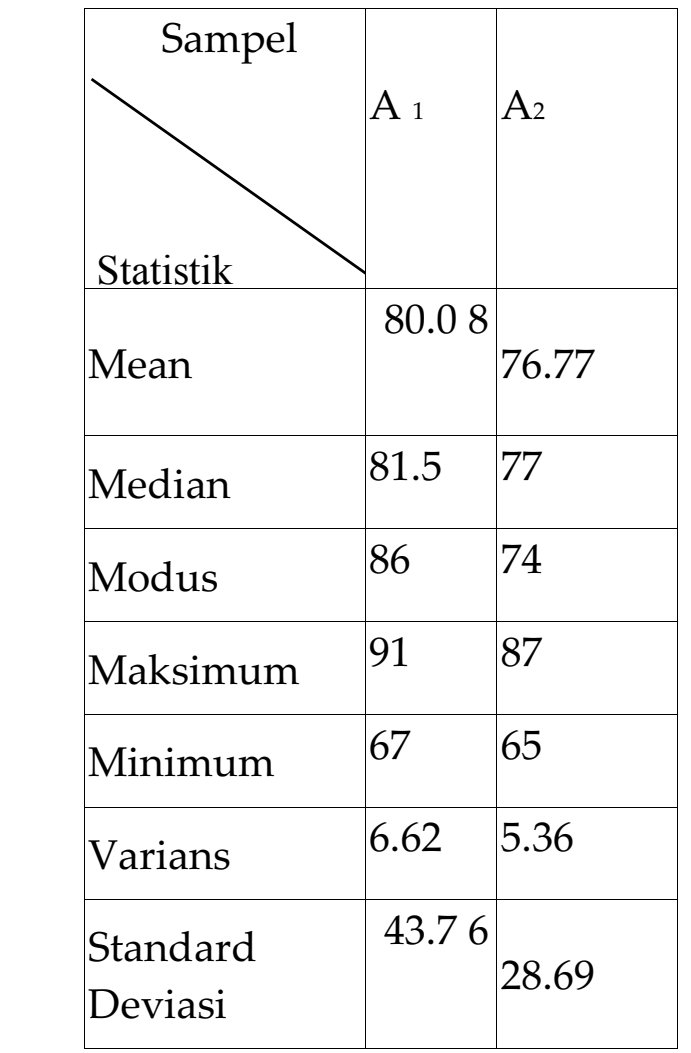

Note

A1 : The group of the students who were treated by using guided writing strategy

A2 : The group of the students who were treated by using conventional writing strategy

\section{Discussion}

Strengthened by the descriptive analysis, it was found that the mean score of writing competency tests for the students who treated by using guided writing strategy was 80.76 and the mean score of writing competency treated by using conventional writing strategy was 76.76. From the mean score finding, it can be concluded that according to the learning strategy, the group of students treated by using a guided writing strategy was better than the students treated by using conventional writing strategy. The conventional strategy in the present study referred to the one which was normally used by the lecturer do.

There were some reasons on why guided writing strategy was

better than the conventional writing strategy. In the experimental class, the students did some steps; the first step was introducing the related topic that was discussed in the class. The students were less interested while the lecturer only explained the topic. They paid more attention when the lecturer showed a picture.

The discussion was the second step. In this step, the lecturer and the students discussed some elements related to the picture. When the lecturer did this step, the students were eager to say anything that came to their minds. The learning environment changed from passive to active way. The students worked in a group in this section to find several aspects of the topic. They also discussed with their group about what the generic structure of the text was.

The third step was questioning. The lecturer told the students to make some questions related to the picture. The students brought their own pictures taken from magazines, newspapers, posters, and a lot of them printed out their pictures. After that, the students wrote their own questions which were later to write their paragraphs. From this activity, the lecturer could check the content of the student's writing.

Brainstorming was the fourth step. The students generated their ideas based on the pictures shown or 
brought in brainstorming. The important thing in this stage was the picture. It inspired the students to get some useful words in writing their paragraphs.

Outlining is the fifth step. That helps the students to selected some relevant ideas and set them as the paragraph outline. The lecturer involved in this step by giving guidance to students. For example, helping the student to decide which idea should put in the first, second, third, until the last. Drafting was the sixth step. Entering this stage, the students were assigned to write a draft based on the outline that they have written. This step was intended to develop relevant ideas into a paragraph.

Revising was the seventh step. After finished drafting, the students should revise their work. They have revised their writing based on the guidance in the form of a checklist provided by the lecturer. In this case, the students did twice revising. First, they should swap their work. After that, they return their friends' work after finish giving revision. Second, they also made their own correction.

Editing was the eighth step. After the students revised their writing, the editing process was the next. They rewrote their writing based on the revising. The students mostly made few revisions on grammar and mechanics.

Sharing was the last step. It was the publishing process. Because of limited time, only a few students could publish their work. The lecturer asked the students to perform or read their work in front of the class in order to show, so the other friends know they're From those nine steps, it is obvious that the students were more intensively guided to write in a step by step procedure. This results in a better writing competency which is in line with Hill's theory (2009). Moreover, Malik (2007) also emphasizes that guided writing strategy can improve students' writing competency because guided writing is able to help the students to build their skills by encouraging them to elaborate their ability and express their ideas in detail to a written product. Additionally, Hill (Department of Education, 2009) states that guided writing can also create a meaningful activity since the students are assigned to write by themselves. This activity becomes meaningful because they are learning through experience by themselves.

\section{Conclusion}

Concerning the research findings and discussion presented in the previous chapter, it can be concluded that, There is a significant effect of guided writing on writing competency. The students' writing competency was better when they were taught by using a guided writing strategy than when they were taught by using the conventional strategy. It indicates that guided writing strategy gave effect to students' writing competency compared to the conventional writing strategy. 


\section{References}

Ary, Donald; Jacobs, Lucy Cheser; Sorensen, Chris; and Razavieh, Asghar. 2010. Introduction to research in education 8 edn. Belmont: Wadsworth Cengage Learning.

Best, J. W. and Kahn, J. V. 2003. Research in Education. Ninth Edition. New Jersey: Prentice Hall,.Inc.

Brown, Douglas H. 2000. Principles of language learning and teaching $4 e d n$. New York: Pearson Educatiom, Inc.

Brown, Douglas H. 2004. Language Assessment: Principles and Classroom Practices. New York: Pearson Educatiom, Inc.

Byrne, Donn. 1988. Teaching Writing Skills. England: Longman Group UK Limited.

Celce-Murcia, M \& Olshtain, Elite. 2000. Discourse and Context I Language Teaching. Cambrifge: University press.

Crow, LD. And Alice Crow. 1989.

Psychology pendidikan. Terjemahan Abd. Rachman Abror. Educational Psychology. Yogyakarta: Nur Cahaya

Curicullum and standard. 2007. Improving Writing with a Focus on a Guided Writing. Deparment for children, schools, and families. Pdf

Eastwood, John, 1999. Oxford practice grammar. Oxford: oxford university press

Eggen, P. \& Kauchak, D. 2012. Strategie and Models for Lecturers: Teaching Content and Thingking
Skills, Sixth Edition.Boston: Pearson Education.

Folse, Keith, S.; Muchmore-Vokoun, April, and, Solomon, Elena Vestri 2010. Great writing 2: Great paragraph 3 edn. Boston: Heinle \& Heinle. Pp. 233-248.

Harmer, Jeremy. 2007. The Practice of English Language Teaching 4edn. Harlow: Pearson Education.

Heaton, J. B. 1988. Writing English Language Test. London and New York. Longman Group (FE) Ltd.

Hornby, A. S. 2006. Oxford Advanced Learner's Dictionary. International Students' Edition. Seventh Edition. New York: Oxford university.

Knowles, Gerald. 1969. The achievement motive. In Rodgers, Frederick A. (ed), Research in Review. Detoid: Wayne State University Press.

Marhaeni, A.A.IN. 2008. Developing Authentic Assessment for English Language teaching. Paper

MCClelland, D. 2010 Achievement Motivation. Available at http://books.google.co.id/book s?hl= id\&lrlearningmotivations $=\operatorname{Rr} 5$ 1txAC mH\&sigsehtml.January 2013.

Murray, Donald.M, 1975. Teach writing as a Process not Product. www.willamette.edu.com accessed on 01 August 2014.

Nunan, David. 2005. Practical English Language Teaching: Young Learners; A textbook for lecturers. New York: Prentice hall 
Oczkus, Lori D. 2007.Guided Writing ( Practical Lesson, Powerful Result). United States America: A division of read Elsevier Inc.

Ormrod, J.E. 2014. How Motivation Affects Learning and Behavior. England. Pearson.

Oshima, Alice and Hogue, Ann. 2007. Introduction to Academic Writing. New York: Pearson Education, Inc.

Raimes, Ann and Jerskey, Maria. 2011. Keys for Writers. Sixth Edition. USA: Wadsworth Cengage Learning.

Richard, Jack C. and Rodger, T.S. 2001. Approaches and Methods in Language teaching. United Kingdom: Cambridge University Press

Sardiman.2011. Interaksi dan Motivasi Belajar Mengajar. Jakarta: PT.Raja Grafindo persada

Schlig, Carmen. 2008. Improving Foreign Language Writing Competence. Georgia State University. http/education.gsu.edu/ctl/flc/schl ig. FLwriting.revised2008.html. Accessed on January, 2014

SIL International, 1999. The four basic language skills.

http:/www.sil.org/lingualinks/l angua ge/learning/otherresourseces/ Gudlns FraLnggandCltrLrnngPrgrm/F ourBa sicLanguageSill.html. accessed on 14 July 2014.

Sugiyono. 2011. Metode

Penelitian Pendidikan:

Pendekatan
Kualitatif, dan RED. Bandung: Alfabeta.

Suharta, I G. P. 2001. "Profil Pembelajaran Matematika Sekolah Dasar". Laporan Penelitian. Singaraja: IKIP

\section{Suprihatiningrum, J. 2012.}

Strategi Pembelajaran (Teori dan Aplikasi). Yogyakarta: Ar-Ruzz Media

Walia, Divya Nimit. 2012. "Traditional Teaching Methods vs. CLT: A Study." Frontiers of Language and Teaching, Vol. 3, pp. 125-131 